\title{
Catalan Imitations of the Ligurian Taches Noires Ware in Barcelona (18th-19th Century): An Example of Technical Knowledge Transfer
}

\author{
Roberta Di Febo $^{1,2, *}$, Lluís Casas ${ }^{3}$ (D), Claudio Capelli ${ }^{4}$ (i), Roberto Cabella 4 ([) \\ and Oriol Vallcorba 5 (D) \\ 1 U Science Tech, MECAMAT Group, University of Vic-Central University of Catalonia, \\ C. de la Laura 13, 08500 Vic, Catalonia, Spain \\ 2 Cultura Material i Arqueometria UB (ARQ। UB, GRACPE), Department de Prehistòria, \\ Història Antiga i Arqueologia, Universitat de Barcelona, c/Montalegre, 6, 08001 Barcelona, Catalonia, Spain \\ 3 Department de Geologia, Universitat Autònoma de Barcelona (UAB), Edifici C, 08193 Cerdanyola del Vallès, \\ Catalonia, Spain; lluis.casas@uab.cat \\ 4 Dipartimento di Scienze della Terra, dell'Ambiente e della Vita (DISTAV), Università degli Studi di Genova, \\ Corso Europa 26, 16132 Genova, Italy; capelli@dipteris.unige.it (C.C.); cabella@dipteris.unige.it (R.C.) \\ 5 ALBA Synchrotron Light Source, Cerdanyola del Vallès, 08290 Barcelona, Catalonia, Spain; \\ ovallcorba@cells.es \\ * Correspondence: roberta.di@uvic.cat; Tel.: +39-34-0855-9415
}

Received: 30 March 2018; Accepted: 24 April 2018; Published: 27 April 2018

\begin{abstract}
The ware called Taches Noires was developed in Albisola (Liguria, NW Italy) during the 18th century. In just a few years, it spread all over the Mediterranean (Italy, France, Spain, Tunisia, and Greece) and also in the New World (Canada, the Caribbean Islands, and Mexico). The success of the Taches Noires ware was so massive that it was soon copied by Spanish and French workshops. A collection of Catalan imitations and Ligurian imports found in Barcelona were analysed and compared to previously existing data from Barcelona productions, as well as reference samples from Albisola. The study proved the presence of both local imitations and original Albisola imports. The analysis showed a homogeneous product of high technical quality for the Albisola pottery. On the contrary, the local imitations presented a greater diversification in the choice and manipulation of the raw materials, probably related to the existence of different workshops engaged in the manufacturing of these products. Nevertheless, for one of the local groups, ceramists adopted a glaze recipe similar to the one used in Albisola, clearly indicating a direct transfer of knowledge, and possibly of potters, from Albisola to Barcelona.
\end{abstract}

Keywords: Albisola; Barcelona; Taches Noires pottery; 18th century AD; provenance; imitations; technical knowledge; archaeometric analyses; kentrolite; hematite

\section{Introduction}

The first evidence of the production of the Taches Noires ware (TNW) in Albisola traces back to the first half of the 18th century in response to the downfall of the Majolica production and competition of the English cream ware [1-3]. The TNW is characterized by fine, hard, deep red fabric and brown transparent glazes decorated with wavy black bands (Figure 1). The most common documented forms are plates, bowls, and to a lesser extent, cooking wares [4]. A detailed description of the TNW manufacturing process can be found in the technical report of the Napoleonic Prefect Chabrol de Volvic [5]. According to him, the paste recipe involved the use of local raw materials, such as red clay and marl, which were mixed in different proportions ( $2 / 3$ of red clay and $1 / 3$ of marl). The pottery 
was fired in two stages; in the second stage, saggars were used to guarantee sufficient oxidising conditions. In fact, these refractory clay containers protected the pottery from sudden changes of temperature, steam, flames, and impurities that could develop during the firing process. The lead used in the glazing mixture was purchased in Genoa (Figure 2) or imported from Almeria (Spain) and mixed with sand from Antibes (France) or ground quartz from Noli (Liguria). The addition of one twelfth of iron oxide gave an orange-brown colour to the glazes, while the manganese decorations were applied under the glazed coat before the second firing. The strategic position of Albisola, not far from the port of Genoa, and the existence of large clay outcrops, certainly favoured a large-scale production. From 1798, 48 workshops produced about 24 million pieces per year, most of these were exported to Piedmont, Tuscany, Sardinia, and outside of Italy to Corsica, France, Spain, Greece, Africa, Canada, the Caribbean Islands, and Mexico [3,6-12]. The major production consisted of little serving-dishes, and subordinately, of large six-side dishes, bowls, mugs, jugs, coffee-pots, candlesticks, and round covered pots. Some shapes are taken from moulds used in the production of majolica and coeval earthenware. The decoration with bands, which was performed with speed and improvisation, was the most common type and was used in serial production [1,12]. The supremacy of Albisola products and Ligurian trade in the western Mediterranean caused a reaction from the Provencal and Spanish potters. Spain (1809) and France (1820) imposed import duties on Ligurian pottery. This damaged the production of the Albisola factory and forced many potters to emigrate to those countries to locally produce the TNW $[1,3,13]$.
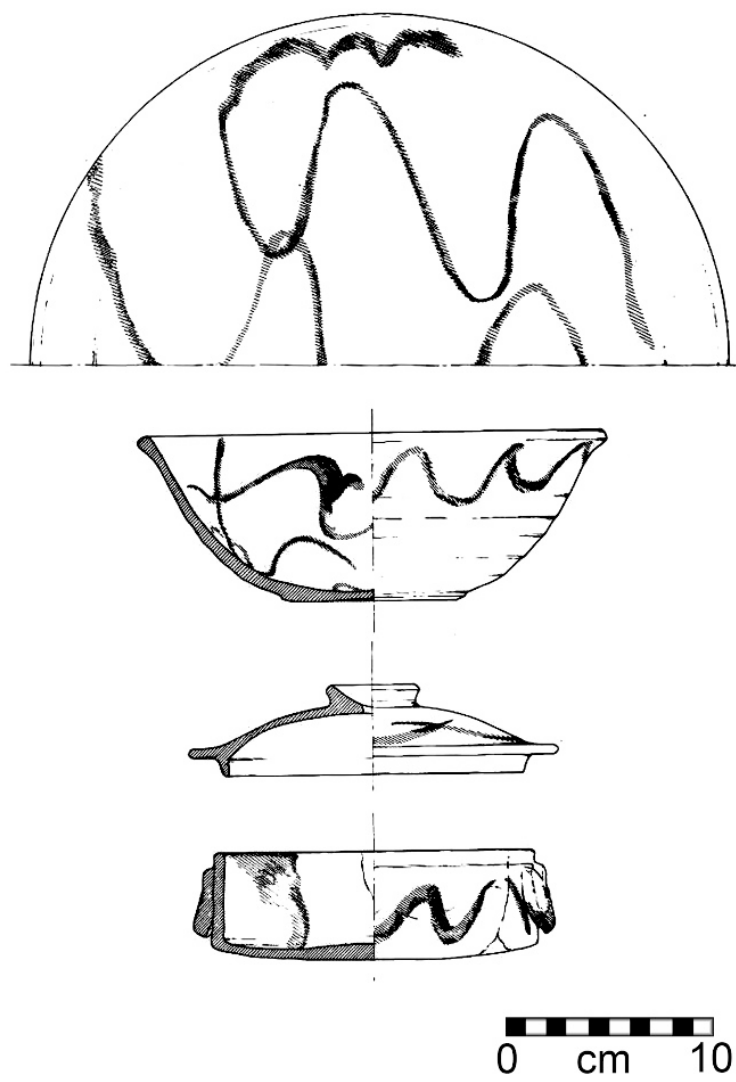

Figure 1. The Albisola Taches Noires pottery, adapted from [4].

This particular type of pottery is very common in Barcelona's archaeological contexts dated from the 18th century. Nevertheless, it is a little known ware, absent from any in-depth study and generically identified as "mourning pottery" (cerámica de duelo) for its dark decoration [14-16]. Detailed archaeometric analyses have been performed on a selected assortment of Taches Noires wares found in Barcelona. Firstly, the pastes have been subjected to petrographic $(\mathrm{OM})$ and chemical 
scanning electron microscopy energy-dispersive spectrometry (SEM-EDS) analyses. The results of the ceramic bodies have been compared to previously reported data from Barcelona productions [16] and Albisola reference samples $[17,18]$. The analyses revealed the presence of two different local imitations as well as original Albisola imports. Furthermore, the glazes and crystallites found in the glaze mixture have been studied by SEM-EDS, micro-Raman spectroscopy ( $\mu$-Raman) and Synchrotron radiation micro-X-ray diffraction (SR- $\mu$ XRD) [19]. The primary aim of this research is to determine the differences and similarities between the local products and the original TNW found in Barcelona, with particular attention to the possible sources of exploited of raw materials, the provenance markers, and the manufacturing technology.

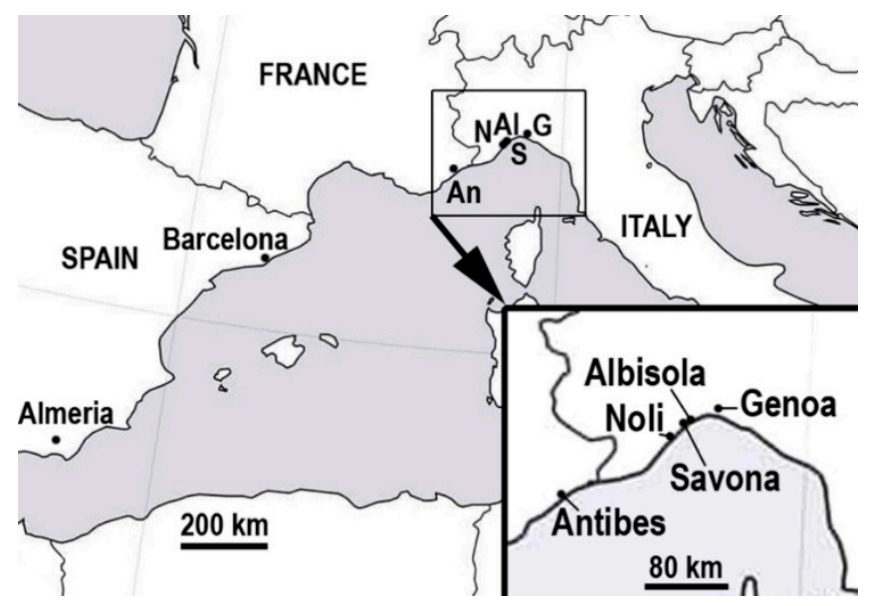

Figure 2. Map of the main sites cited in the text. G: Genoa; Al: Albisola; S: Savona; N: Noli; An: Antibes; Barcelona; Almeria.

\section{Materials and Methods}

A set of 20 pottery shards of TNW were selected for this study (Table 1 and Figure 3). Two artefacts were macroscopically identified as Albisola imports. These show thin walls, hard, red, and sonorous bodies, shiny dark brown/brown glazes, and decorations with wavy black bands; 18 artefacts were recognized as imitations of the Ligurian TNW. They exhibit thicker walls, usually lighter coloured bodies, honey brown/brown glazes, and decorations consisting of black/dark brown bands or lines. The Albisola reference samples used for the compared analyses are dated from the 18th century and come from the University of Genova. They are plates of high aesthetic quality. They display oxidized red bodies, thin walls, brown and shiny glazes, while the dark decorations consist of black bands.

Preliminary examination of the bodies and glazes was undertaken using a stereomicroscope, and then, in thin section, using an Olympus BX41 polarizing microscope. In addition, polished thin sections of all the glazes were also examined under reflected light. The bulk chemical compositions of both bodies and glazes were determined using an energy-dispersive spectrometer (EDS), attached to the SEMs (Vega3, TESCAN), at the University of Genova (Genova, Italy) and Girona (Girona, Spain). The instruments were typically operated at $20 \mathrm{kV}$, a beam current of $1.2 \mathrm{nA}$, and an overall count time of $100 \mathrm{~s}$. The concentration measurements of the individual elements were obtained with respect to the External Standards of natural and synthetic origin, applying the ZAF correction. Analytical precision was checked by analysing the standards, it was confirmed by $1 \%$ for the major elements and $3-5 \%$ for the minor ones with detection limits of about 500 ppm. The SEM-EDS average compositions, expressed in $\mathrm{wt} \%$, in oxides, were normalized; $100 \%$ were recalculated. Wide raster analyses of the ceramic bodies were obtained by scanning the beam over large areas (ca. $3.7 \times 2.8 \mathrm{~mm}^{2}$ ). Bulk analyses of the whole glaze layer were obtained by scanning areas slightly less than glaze thickness. Weathered or contaminated surface layers and glaze-body interfaces were avoided, such as mineral inclusions. $\mu$-Raman analyses were carried out directly on the polished thin sections of the glazes at the Centres 
Científics i Tecnològics (CCiTUB), University of Barcelona (Barcelona, Spain). Spectra were obtained with a HORIBA Jobin Yvon LabRam HR 800 dispersive spectrometer, equipped with an Olympus BXFM optical microscope using a $600 \mathrm{~g} / \mathrm{mm}$ grating and a Synapse CCD detector cooled to $-70{ }^{\circ} \mathrm{C}$.

The $\mu$-Raman spectra reported in this study were recorded with the $532 \mathrm{~nm}$ excitation line of a solid-state laser. Reliable reference spectra are essential for the correct use of the information obtained by $\mu$-Raman spectroscopy. Therefore, 3 samples of natural hematite from the Collection of Minerals and Rocks of the University of Barcelona (UB, Barcelona, Spain) were used as reference patterns for the $\mu$-Raman study. Natural hematite, in the form of single crystal, was studied by laser $\mu$-Raman at various laser powers to test the thermal effect of the laser beam and avoid erroneous assignments.

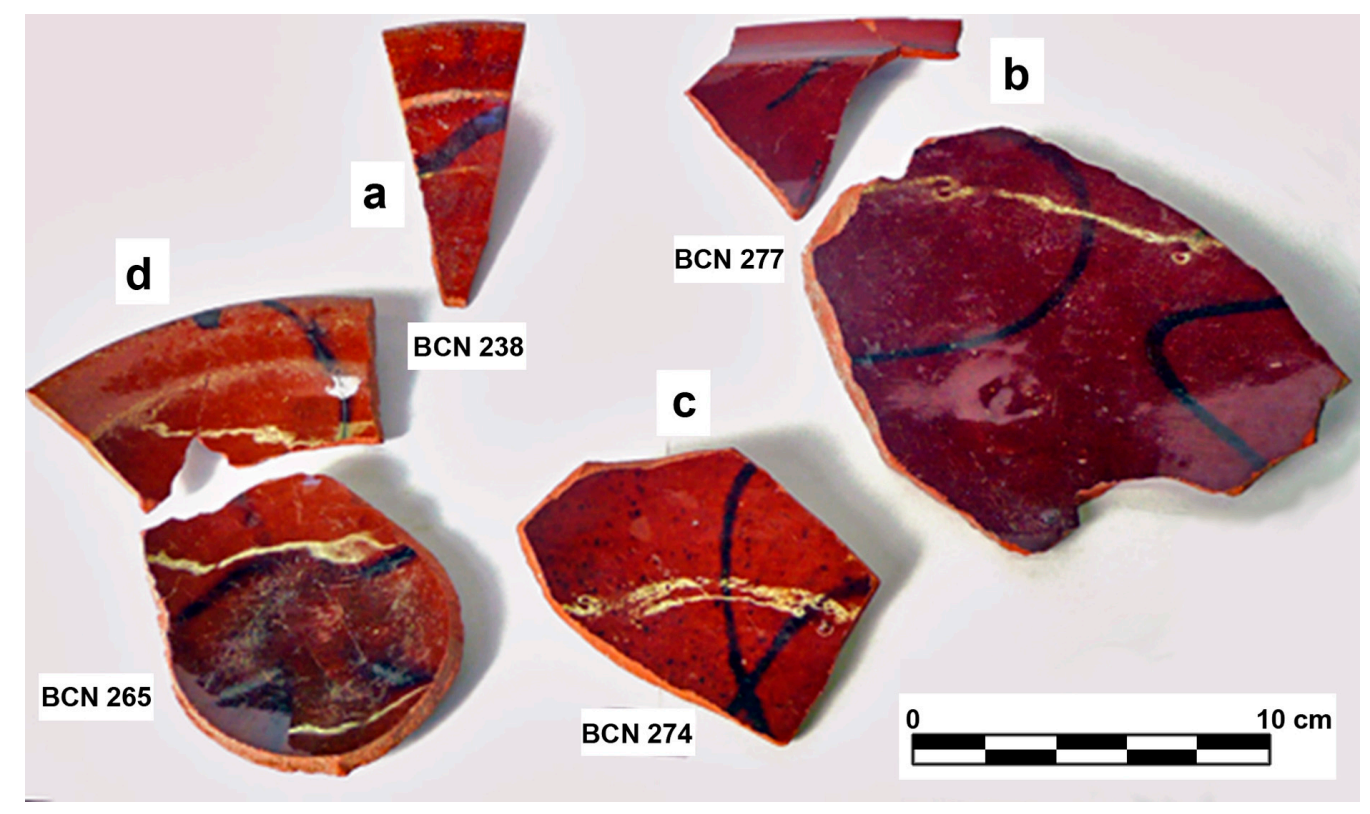

Figure 3. Examples of Taches Noires pottery from Barcelona: (a) Albisola import; (b-d) local imitations of the Ligurian Taches Noires ware.

The micro-crystallites of the brown decorations were studied by radiation micro-X-ray diffraction (SR- $\mu-X R D)$ (ALBA Synchrotron, Barcelona, Spain). The latter was performed on the focused-beam station of the beamline BL04 [20] at the ALBA Synchrotron (Cerdanyola del Vallès, Spain). The areas of interest from the polished thin sections were selected using an on-axis visualisation system and were measured by transmission geometry with a focused beam of $15 \times 15 \mu \mathrm{m}^{2}$ (full width at half-maximum). The energy used was $29.2 \mathrm{keV}(\lambda=0.4246 \AA)$ and the diffraction patterns were recorded with a Rayonix SX165 CCD detector (active area of $165 \mathrm{~mm}$ diameter, frame size $2048 \times 2048$ pixels, $79 \mu \mathrm{m}$ pixel size, and dynamic range 16 bit). The calibration of the sample-detector distance and beam centre (from a LaB6 sample measured in the same conditions) and the radial integration of the images were performed with the Fit2D software [21]. Phase identification was performed using PANalytical HighscorePlus software using integrated PDF-2 database (ICDD). 
Table 1. Summary of the studied shards according to their typological, stylistic, and macroscopic description as well as their poresumed provenance and date .

\begin{tabular}{|c|c|c|c|c|c|c|}
\hline Code & Sample & Typological Class & Glaze Colour & Decoration & Provenance & Date (Century AD) \\
\hline $072 / 86$ & BCN238 & Dish & Shiny brown & Black bands & Albisola & 2nd half 18 th \\
\hline 09/01 & BCN239 & Dish & Honey-brown & Black bands & Barcelona & 18th \\
\hline 09/01 & BCN265 & Dish & Brown & Black lines & Barcelona & 18th \\
\hline 09/01 & BCN266 & Dish & Brown & Dark brown bands & Barcelona & 18th \\
\hline 09/01 & BCN267 & Dish & Brown & Dark brown bands & Barcelona & 18th \\
\hline 09/01 & BCN268 & Dish & Brown & Dark brown lines & Barcelona & 18th \\
\hline $09 / 01$ & BCN269 & Dish & Brown & Dark brown lines & Barcelona & 18th \\
\hline 09/01 & BCN270 & Dish & Brown & Black lines & Barcelona & 18th \\
\hline $09 / 01$ & BCN271 & Dish & Honey brown & Dark brown lines & Barcelona & 18th \\
\hline 09/01 & BCN272 & Dish & Honey brown & Dark brown lines & Barcelona & 18th \\
\hline $09 / 01$ & $\mathrm{BCN} 273$ & Dish & Brown & Dark brown lines & Barcelona & 18th \\
\hline $09 / 01$ & $\mathrm{BCN} 274$ & Dish & Brown & Black crossed lines & Barcelona & 2 nd half 18 th \\
\hline $55 / 03$ & BCN275 & Dish & Shiny dark brown & Black bands & Albisola & 18th \\
\hline 096/06 & BCN276 & Dish & Brown & Dark brown lines & Barcelona & Late 18th \\
\hline 096/06 & BCN277 & Dish & Shiny dark brown & Black bands & Barcelona & Late 18th \\
\hline 096/06 & $\mathrm{BCN} 278$ & Dish & Honey-brown & Dark brown crossed lines & Barcelona & Late 18th \\
\hline 096/06 & BCN279 & Dish & Brown & Dark brown bands & Barcelona & Late 18th \\
\hline 096/06 & BCN280 & Dish & Honey-brown & Black bands & Barcelona & Late 18th \\
\hline 096/06 & BCN281 & Dish & Brown & Black bands & Barcelona & Late 18 th \\
\hline 096/06 & BCN282 & Dish & Honey-brown & Black bands & Barcelona & Late 18th \\
\hline
\end{tabular}

\section{Results}

\subsection{The Ceramic Bodies}

\subsubsection{Petrographic Analysis}

Petrographic analysis shows three main fabrics (Table 2). Group TN1 includes the Albisola imports, while the local imitations are classified in two other groups (TN2 and TN3). Fabrics are defined according to their petrographic and textural features.

TN1: Very Fine to Fine Fabric with Mica Crystals (BCN238 and BCN275) (Figure 4a)

This petrofabric group is characterised by a moderate ferric, well-oxidized, and vitrified matrix. Inclusions are very abundant and are mainly composed of subangular and subrounded crystals of quartz and K-feldspars, biotite, white mica flakes, and partially or completely decomposed fragments of calcareous microfossils (globigerinae and undetermined foraminifera). Subordinate iron oxides, amphiboles, and rarer amounts of metamorphic rock fragments such as plagioclase, epidote, tourmaline, and siliceous microfossils also occur. Voids (meso-voids) are scarce and occur as vughs and channels.

From the petrographic point of view, this group exhibits precise comparisons with the Albisola reference materials $[17,18]$. All the pastes show similar petrographic features and the inclusions are compatible with the local Fe-rich alluvial clays, Pliocene marine marls, and sands derived from the Palaeozoic metamorphic basement outcropping in the coastal belt between Vado Ligure and Albisola [22].

TN2: Very Fine to Medium Fabric with Large Biotite Crystals (BCN 239, BCN266, BCN267, BCN277, BCN279, BCN280, and BCN281)

This petrofabric group shows a non-calcareous matrix with abundant subangular and subrounded inclusions. Quartz, K-feldspar, and biotite are the main constituents, accompanied by sparse amounts of metamorphic rock fragments, iron oxides, and a rare presence of plagioclase, white mica, and heavy minerals. Meso-voids predominantly occur as vesicles and vughs. However, considering the differences in the textural features (sorting, size distribution, and packing), TN2 can be divided in three subgroups: TN2A, TN2B, and TN2C (Figure 4b-d). 

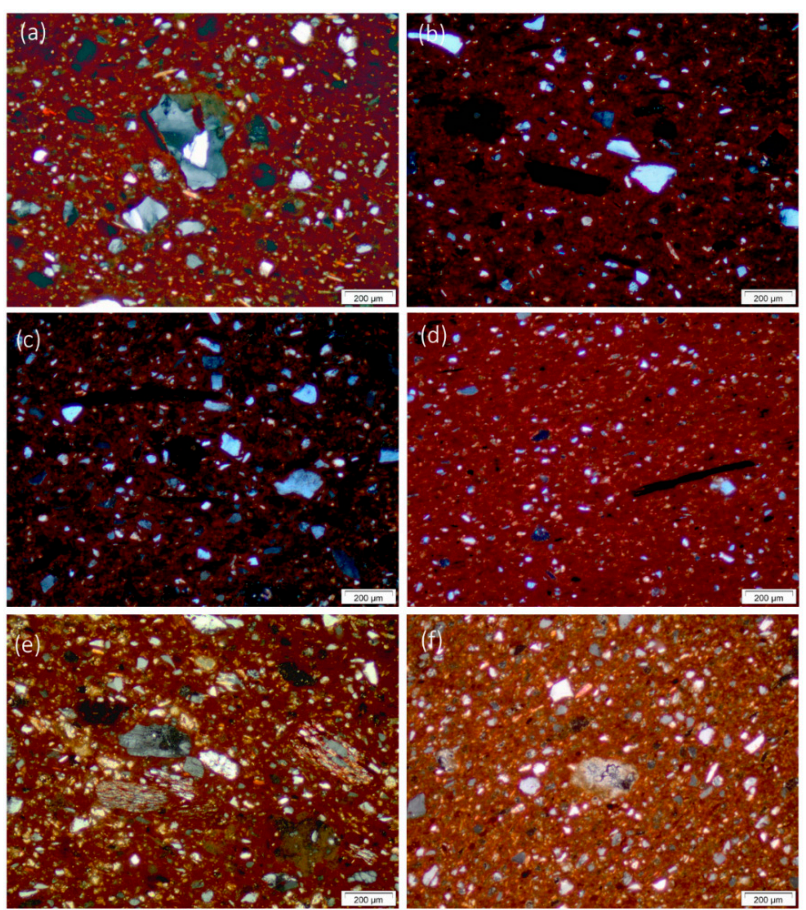

Figure 4. (a) Photomicrograph of the sample BCN275 (crossed polarized light $=$ XPL). In the centre of the photo, it is possible to see a metamorphic rock fragment; (b) photomicrograph of the sample BCN 279 (TN2A subgroup, crossed polarized light $=$ XPL). Biotite crystals can be observed; $(\mathbf{c})$ photomicrograph of the sample BCN266 (TN2B subgroup, crossed polarized light $=$ XPL). This contains very fine-medium grained inclusions which occur more frequently; (d) photomicrograph of the sample BCN281 (TN2C subgroup, crossed polarized light $=\mathrm{XPL})$. This subgroup represents the most fine-grained fabric; (e) photomicrograph of the sample BCN269 (TN3B subgroup, crossed polarized light $=$ XPL). In the centre of the photo, it is possible to see some fragments of phyllite; (f) photomicrograph of the sample BCN282 (TN3A subgroup, crossed polarized light $=$ XPL). This is similar to TN3B in terms of textural characteristics, but different for the lack of phyllite fragments and lesser calcareous microfossils.

TN3: Very Fine to Fine Fabric with Metamorphic Rock Fragments (BCN265, BCN268, BCN269, BCN270, BCN271, BCN272, BCN273, BCN274, BCN276, BCN278, and BCN282)

This petrofabric group is characterized by a well-oxidized and relatively vitrified calcareous matrix. The calcareous microfossils, which appear partially decomposed and recrystallized, prevail over quartz and K-feldspars, while biotite flakes are not particularly abundant. Metamorphic rock fragments and iron oxides are sparsely distributed in the matrix, while plagioclase, white mica, amphibole, and tourmaline appear scarcely. Meso-voids are frequent, in particular, channels and vughs, although macro-voids also occur. Minor variations in the frequency of some inclusions make possible to differentiate two subgroups: TN3A and TN3B (Figure 4e,f). In particular, the samples of subgroup TN3A are differentiated from TN3B by the absence of phyllite fragments and the lesser calcareous microfossils.

Concerning the provenance of TNW imitations, local attribution is based on available references from the geology of Barcelona. The metamorphic inclusions, presented in variable amount in all the pastes, are compatible with the range of geological circum-local deposits [23]. From the comparison with the Barcelona local productions using the ARQ I UB database [24], the ceramic pastes of TN2 and TN3 display a mineralogy and texture highly similar to the ones of the two different productions of brown glazed wares dated from the 18th century [16]. Therefore, the use of a comparable paste recipe for these types of productions could be suggested. 
Table 2. Petrographic groups of the ceramic samples studied. Abbreviations: A, angular; SA, subangular; SR, subrounded; R, rounded; Ph, phyllite; Gr, granitoid; Qmsch, quartz-micaschist; Gn, gneiss; Amph, amphibolite; Qz, quartz; Pl, plagioclase; Kfs, K-feldespar; Bt, biotite, Ms, muscovite; Ox; Iron Oxides, Ep, epidote; Amp, amphibole; C. Fos, calcareous microfossils; S. Fos, siliceous microfossils; Tur, tourmaline. Relative quantity: xxxx, frequent; xxx, common; xx, few; $x$, rare.

\begin{tabular}{|c|c|c|c|c|c|c|c|}
\hline \multicolumn{2}{|c|}{ Petrographic Group } & $\begin{array}{c}\text { TN1 } \\
(\mathrm{BCN} 238,275)\end{array}$ & $\begin{array}{c}\text { TN2A } \\
\text { (BCN239, 279) }\end{array}$ & $\begin{array}{c}\text { TN2B } \\
(\mathrm{BCN} 266,267) \\
\end{array}$ & $\begin{array}{c}\text { TN2C } \\
\text { (BCN277, 280, 281) }\end{array}$ & $\begin{array}{c}\text { TN3A } \\
\text { (BCN278, 282) } \\
\end{array}$ & $\begin{array}{c}\text { TN3B } \\
(265,268,269,270,271,272,273,274,276)\end{array}$ \\
\hline \multicolumn{2}{|c|}{ Glaze th $(\mu \mathrm{m})$} & $100-200$ & 100-200 & $100-150$ & $100-200$ & $150-200$ & $150-350$ \\
\hline \multicolumn{2}{|c|}{ Fabric } & very fine-fine sand & very fine-medium sand & very fine-medium sand & very fine-fine sand & very fine-fine sand & very fine-fine sand \\
\hline \multicolumn{2}{|c|}{ General Inclusion Size $(\mu \mathrm{m})$} & $<100-200$ & $<100-300$ & $<100-350$ & $<100-100$ & $<100-200$ & $<100-250$ \\
\hline Inclusion Shape & $\begin{array}{c}\text { A } \\
\text { SA } \\
\text { SR } \\
\text { R }\end{array}$ & $\begin{array}{l}x \\
x \\
x\end{array}$ & $\begin{array}{l}x \\
x\end{array}$ & $\begin{array}{l}\mathrm{x} \\
\mathrm{x} \\
\mathrm{x}\end{array}$ & $\begin{array}{l}x \\
x\end{array}$ & $\begin{array}{l}\mathrm{x} \\
\mathrm{x} \\
\mathrm{x}\end{array}$ & $\begin{array}{l}\mathrm{x} \\
\mathrm{x} \\
\mathrm{x} \\
\mathrm{x}\end{array}$ \\
\hline $\begin{array}{l}\text { Inclusion } \\
\text { Composition }\end{array}$ & $\begin{array}{c}\mathrm{Ph} \\
\text { Gr } \\
\text { Qmsch } \\
\text { Gn } \\
\text { Amph } \\
\text { Qz } \\
\text { Pl } \\
\text { Kfs } \\
\text { Bt } \\
\text { Ms } \\
\text { Ox } \\
\text { Ep } \\
\text { Amp } \\
\text { C. Fos } \\
\text { S. Fos } \\
\text { Tur }\end{array}$ & $\begin{array}{c}x \\
x \\
x x x \\
x \\
x x x \\
x x \\
x x x \\
x x \\
x \\
x x \\
x x x \\
x \\
x \\
x\end{array}$ & $\begin{array}{c}x \\
x \\
\\
x x x \\
x \\
x x x \\
x x x \\
x \\
x \\
x \\
x \\
\\
x\end{array}$ & $\begin{array}{c}x \\
\\
x x x x \\
x x \\
x x x x \\
x x x x \\
x \\
x x \\
x \\
x \\
x \\
x\end{array}$ & $\begin{array}{c}x x x x \\
x \\
x x x x \\
x x x x \\
x \\
x x \\
x \\
x x \\
\\
x\end{array}$ & $\begin{array}{c}x \\
\\
x x x \\
x \\
x x x \\
x \\
x x \\
x x \\
x \\
x \\
x x \\
x\end{array}$ & $\begin{array}{c}\mathrm{xx} \\
\mathrm{x} \\
\mathrm{x} \\
\\
\mathrm{xxx} \\
\mathrm{x} \\
\mathrm{xxx} \\
\mathrm{xx} \\
\mathrm{xx} \\
\mathrm{x} \\
\mathrm{x} \\
\mathrm{x} \\
\mathrm{xxx} \\
\mathrm{x}\end{array}$ \\
\hline \multicolumn{2}{|c|}{$\begin{array}{l}\text { Porosity } \\
\text { approx. Void Size }(\mu \mathrm{m})\end{array}$} & $50-200 \mu \mathrm{m}$ & $50-200 \mu \mathrm{m}$ & $100-300 \mu \mathrm{m}$ & $50-100 \mu \mathrm{m}$ & $50-300 \mu \mathrm{m}$ & $50-600 \mu \mathrm{m}$ \\
\hline
\end{tabular}




\subsubsection{Chemical Analysis}

Microchemical data obtained by SEM-EDS analyses validates the petrographic results, with regard to the presence of the three different productions (Table 3 and Figure 5). TN1 and TN2 present higher magnesium contents than TN3. These values are linked to the occurrence of biotites and amphiboles in TN1, while very common biotite inclusions in TN2 are responsible for the concentrations observed. TN2 is clearly distinguishable from TN3, due to low calcium content, which suggests the use of different raw materials in the paste recipe. The high calcium content observed in TN3 is related to the use of a calcareous clay and the presence of calcareous microfossils, except for BCN278 and BCN282 samples, which are less rich in calcareous components. SEM analyses confirmed the earlier $X$ ray-florescence analyses (XRF) on ceramic bodies [16]. In this respect, TN1 was also distinguishable from the Barcelona local productions (TN2 and TN3) by its high magnesium as well as nickel and chromium concentrations (see Table 21 from Annex 1 in [16]). XRF analyses on TN1 were comparable to Ligurian reference materials from the ARQ I UB database, confirming the initial assumption, which assigned TN1 samples to the Albisola productions [16].

(a)
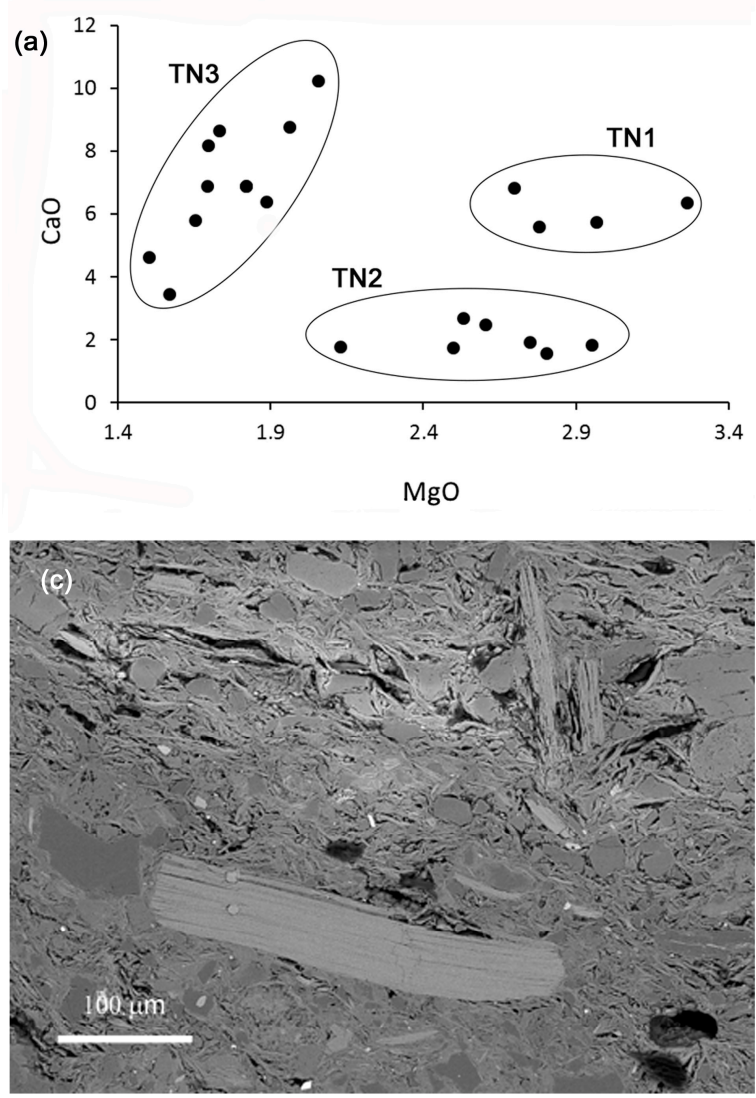
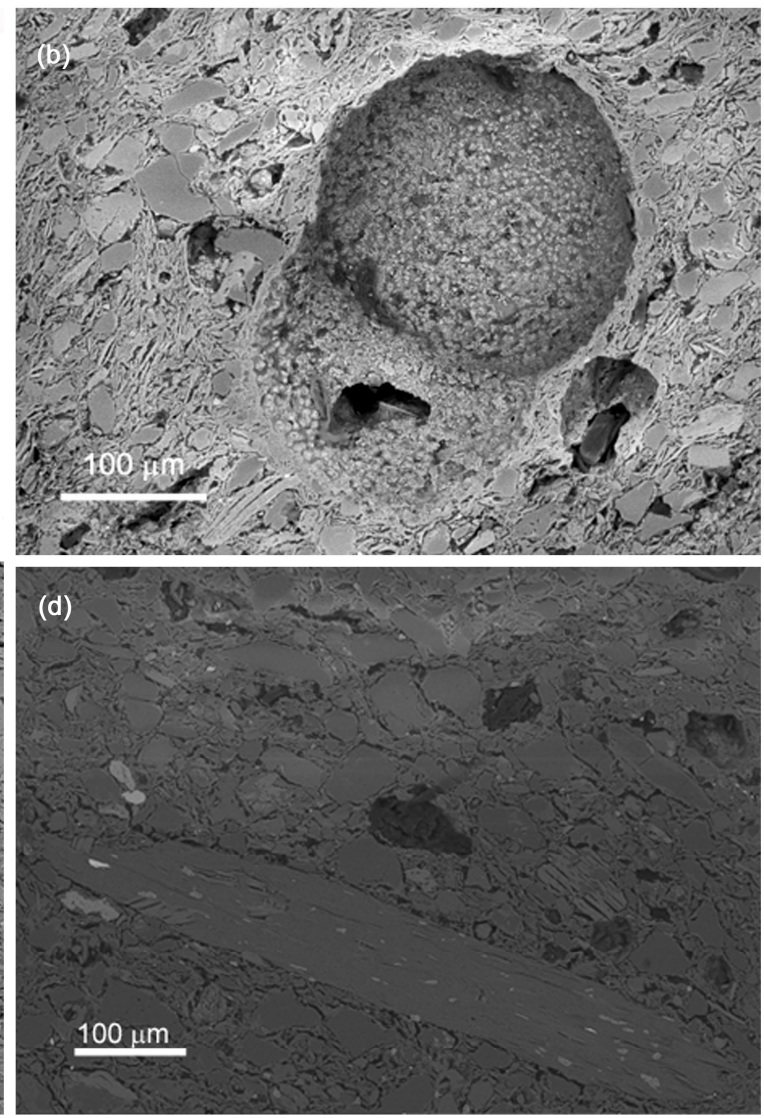

Figure 5. (a) Plot of $\mathrm{CaO}$ vs. $\mathrm{MgO}$ contents (wt \%) for the studied samples; (b-d) details of the backscattered electron (BSE) images of the ceramic bodies; (b) TN1, sample BCN238. A calcareous microfossil (globigerina) can be observed in the matrix; (c) TN2, sample BCN279. Large biotite crystals are common in TN2 paste, as illustrated in this picture; (d) TN3, sample BCN269. A large fragment of phyllite can be observed in the clay matrix. 
Table 3. The scanning electron microscopy energy-dispersive spectrometry (SEM-EDS) compositions of the ceramic bodies (recalculated to $100 \mathrm{wt} \%$, as the sum of the different oxides). Asterisks are used to indicate the reference samples from Albisola (TN0001, TN0002).

\begin{tabular}{|c|c|c|c|c|c|c|c|c|c|c|c|}
\hline Sample & Chemical Group & $\mathrm{Na}_{2} \mathrm{O}$ & $\mathrm{MgO}$ & $\mathrm{Al}_{2} \mathrm{O}_{3}$ & $\mathrm{SiO}_{2}$ & $\mathrm{P}_{2} \mathrm{O} 5$ & $\mathrm{~K}_{2} \mathrm{O}$ & $\mathrm{CaO}$ & $\mathrm{TiO}_{2}$ & $\mathrm{MnO}$ & $\mathrm{FeO}$ \\
\hline BCN238 & TN1 & 1.82 & 2.97 & 16.46 & 65.20 & 0.78 & 1.58 & 5.72 & 0.63 & 0.17 & 3.91 \\
\hline BCN275 & TN1 & 1.65 & 2.70 & 16.10 & 62.34 & 1.96 & 2.23 & 6.81 & 0.85 & 0.13 & 5.24 \\
\hline TN0001 * & TN1 & 1.49 & 2.78 & 16.29 & 66.65 & 0.51 & 2.16 & 5.59 & 0.76 & 0.10 & 4.93 \\
\hline TN0002* & TN1 & 1.89 & 3.26 & 17.17 & 63.76 & 0.45 & 1.85 & 6.34 & 0.75 & 0.12 & 4.40 \\
\hline BCN239 & TN2 & 1.60 & 2.60 & 21.25 & 56.36 & 0.39 & 3.78 & 2.48 & 1.31 & 0.16 & 10.06 \\
\hline BCN266 & TN2 & 2.39 & 2.50 & 20.12 & 62.65 & 0.70 & 3.12 & 1.74 & 0.91 & 0.16 & 5.70 \\
\hline BCN267 & TN2 & 1.97 & 2.13 & 15.59 & 70.93 & 0.34 & 2.54 & 1.77 & 0.66 & 0.14 & 3.92 \\
\hline BCN277 & TN2 & 1.97 & 2.80 & 18.23 & 67.53 & 0.67 & 2.36 & 1.58 & 0.79 & 0.14 & 3.93 \\
\hline BCN279 & TN2 & 1.38 & 2.53 & 18.81 & 61.64 & 0.47 & 3.30 & 2.69 & 1.15 & 0.20 & 7.85 \\
\hline BCN280 & TN2 & 1.61 & 2.75 & 20.82 & 57.56 & 0.30 & 3.50 & 1.93 & 1.34 & 0.26 & 9.93 \\
\hline BCN281 & TN2 & 1.57 & 2.95 & 21.05 & 59.17 & 0.47 & 3.27 & 1.85 & 1.22 & 0.18 & 8.29 \\
\hline BCN278 & TN3 & 0.65 & 1.50 & 15.77 & 66.85 & 0.51 & 3.12 & 4.62 & 0.91 & 0.14 & 5.92 \\
\hline BCN282 & TN3 & 0.84 & 1.57 & 15.79 & 69.62 & 0.54 & 2.84 & 3.45 & 0.72 & 0.16 & 4.47 \\
\hline BCN265 & TN3 & 1.15 & 1.69 & 14.65 & 67.92 & 0.99 & 2.27 & 6.89 & 0.73 & 0.14 & 3.57 \\
\hline BCN268 & TN3 & 1.46 & 1.96 & 18.57 & 56.75 & 0.39 & 3.16 & 8.75 & 1.06 & 0.23 & 7.67 \\
\hline BCN269 & TN3 & 1.23 & 1.89 & 15.19 & 66.98 & 0.58 & 2.46 & 6.37 & 0.88 & 0.14 & 4.28 \\
\hline BCN270 & TN3 & 1.22 & 1.82 & 15.17 & 66.75 & 0.77 & 2.53 & 6.87 & 0.71 & 0.06 & 4.09 \\
\hline BCN271 & TN3 & 1.22 & 1.82 & 15.17 & 66.75 & 0.77 & 2.53 & 6.87 & 0.71 & 0.06 & 4.09 \\
\hline BCN272 & TN3 & 1.06 & 2.06 & 17.76 & 56.87 & 0.65 & 3.02 & 10.23 & 1.01 & 0.21 & 7.14 \\
\hline $\mathrm{BCN} 273$ & TN3 & 0.64 & 1.70 & 16.29 & 61.84 & 0.15 & 3.28 & 8.18 & 1.02 & 0.24 & 6.67 \\
\hline BCN274 & TN3 & 0.72 & 1.65 & 16.32 & 65.37 & 0.59 & 3.00 & 5.79 & 0.80 & 0.17 & 5.59 \\
\hline BCN276 & TN3 & 0.90 & 1.73 & 17.92 & 58.19 & 0.65 & 3.28 & 8.65 & 0.94 & 0.19 & 7.54 \\
\hline
\end{tabular}

\subsection{Glazes}

Macroscopically, the glazes can be distinguished by their colour, decoration, and thickness. TN1 and TN2 exhibit relatively thin (100-200 $\mu \mathrm{m})$ dark brown/brown glazes, decorated with wavy bands. On the contrary, TN3 displays thicker $(150-350 \mu \mathrm{m})$ honey-brown/brown glazes, with an informal decorative style. Their chemical composition (Table 4) shows a high lead (47-54\% $\mathrm{PbO}$ ) and iron $(2.80-5.60 \% \mathrm{FeO})$ content, low alkali concentration $\left(\mathrm{Na}_{2} \mathrm{O}+\mathrm{K}_{2} \mathrm{O}\right.$ normally $\left.<2 \%\right)$, and aluminium ranging from 2.60 to $6.65 \% \mathrm{Al}_{2} \mathrm{O}_{3}$. In general, the contact of the glaze with the body is regular and shows a moderately developed glaze-body interface. The latter is composed of lead feldspars and neo-formed hexagonal hematite crystallites [25]. These appear as light thin laminar sections in backscattered electron (BSE) images (Figure 6a,b). Concerning the glaze recipe, TN1 and TN2 are clearly distinguishable from TN3 by the presence of relict silicate inclusions (quartz and feldspar) and iron oxides (Figure 7a-c). Raman spectra obtained from different crystals of Fe-oxides show the typical Raman bands of hematite (Figure 7c,d). Both spot and area analysis of the decorations revealed that the Mn contents dissolved into the glaze were relatively low in concentration $(0.50-1.45 \% \mathrm{MnO})$. The decorations of TN2 were found near to the glaze-body interface and were formed by kentrolite $\left(\mathrm{Pb}_{2} \mathrm{Mn}_{2} \mathrm{Si}_{2} \mathrm{O}_{9}\right)$ crystals (Figure 8a,b). On the contrary, neither manganese oxides nor other Mn-rich crystallites were found in the glazes of TN1 or TN3. 
Table 4. Chemical compositions (mean and standard deviation) of the TNW glazes for the groups cited in the text (wt \%); n.d., not detected.

\begin{tabular}{|c|c|c|c|c|c|c|c|c|c|c|c|}
\hline Fabric Group & Area Analysis & $\mathrm{Na}_{2} \mathrm{O}$ & $\mathrm{MgO}$ & $\mathrm{Al}_{2} \mathrm{O}_{3}$ & $\mathrm{SiO}_{2}$ & $\mathrm{PbO}$ & $\mathrm{K}_{2} \mathrm{O}$ & $\mathrm{CaO}$ & $\mathrm{TiO}_{2}$ & $\mathrm{MnO}$ & $\mathrm{FeO}$ \\
\hline \multirow{2}{*}{ TN1 (BCN238) } & brown area & 0.44 & 0.85 & 4.93 & 35.79 & 50.85 & 1.14 & 1.47 & 0.37 & n.d. & 4.18 \\
\hline & decoration & 0.49 & 0.7 & 4.8 & 36.56 & 49.45 & 1.09 & 1.51 & 0.36 & 1.32 & 3.73 \\
\hline \multirow{2}{*}{ TN1 (BCN275) } & brown area & 0.82 & 0.61 & 4.18 & 41.08 & 44.96 & 0.78 & 1.31 & 0.70 & n.d. & 5.59 \\
\hline & decoration & 0.45 & 0.60 & 2.60 & 34.72 & 53.65 & 0.66 & 0.88 & 0.36 & 1.45 & 4.63 \\
\hline \multirow{2}{*}{$\begin{array}{c}\text { TN2 (BCN239, 266, 267, 277, } \\
279,280,281)\end{array}$} & brown area & $0.40(0.20)$ & $0.68(0.14)$ & $4.60(0.18)$ & $36.12(1.67)$ & $52.40(2.27)$ & $0.81(0.27)$ & $0.77(0.31)$ & $0.41(0.09)$ & n.d. & $3.77(0.69)$ \\
\hline & decoration & $0.40(0.15)$ & $0.73(0.17)$ & $4.80(0.36)$ & $34.90(2.66)$ & $52.65(2.79)$ & $0.82(0.30)$ & $0.85(0.21)$ & $0.39(0.15)$ & $0.52(0.38)$ & $3.91(0.78)$ \\
\hline \multirow{2}{*}{$\begin{array}{c}\text { TN3 (BCN265, 268, 269, 270, 271, } \\
272,273,274,276,278,282)\end{array}$} & brown area & $0.33(0.16)$ & $0.81(0.18)$ & $6.61(1.34)$ & $37.82(4.27)$ & $48.71(6.28)$ & $0.99(0.35)$ & $1.20(0.73)$ & $0.55(0.17)$ & n.d. & $2.81(0.54)$ \\
\hline & decoration & $0.36(0.13)$ & $0.84(0.16)$ & $6.65(1.13)$ & $37.69(3.40)$ & 47.29 (5.64) & $0.99(0.36)$ & $1.32(0.74)$ & $0.61(0.08)$ & $1.35(1.02)$ & $2.91(0.50)$ \\
\hline
\end{tabular}



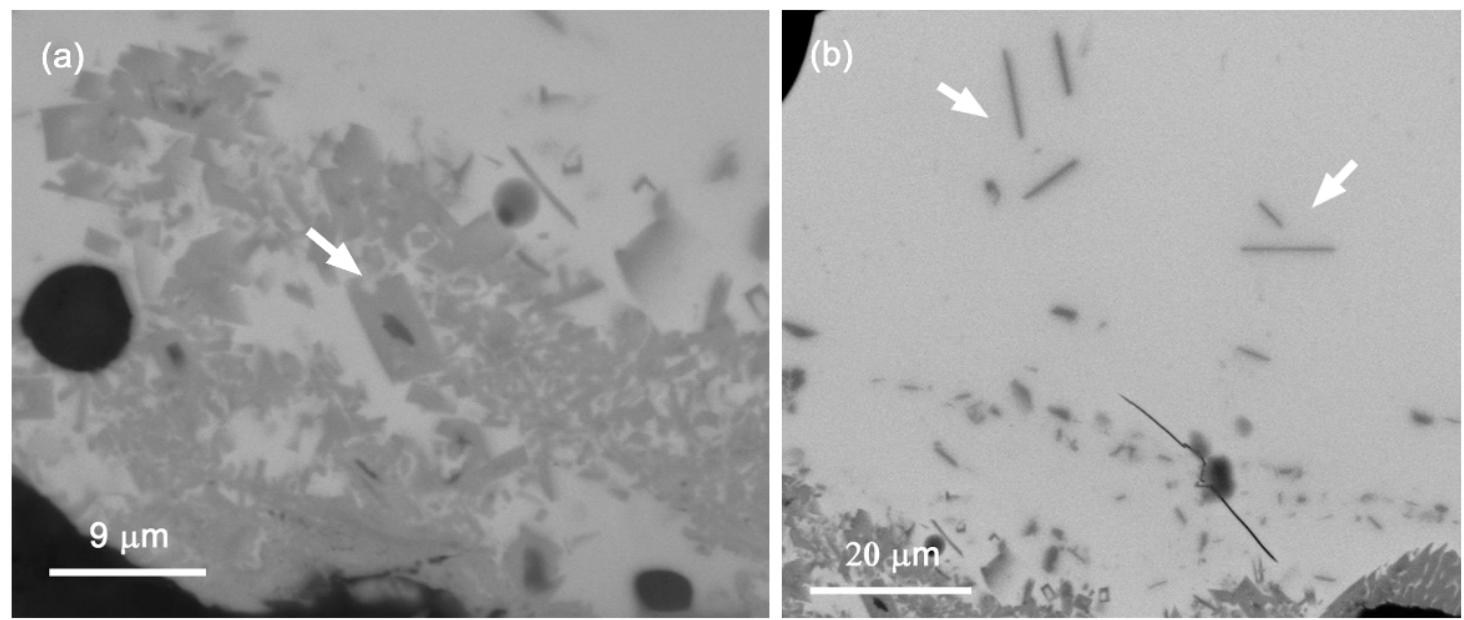

Figure 6. BSE images of the glazes. (a) Lead feldspar, indicated with an arrow, is visible in the ceramic-body interface (BCN266, TN2); (b) on the polished surface, the growth habit of the hexagonal crystallites of hematite is missing, and therefore, some light thin laminar sections (indicated with white arrows) are visible (BCN266, TN2).
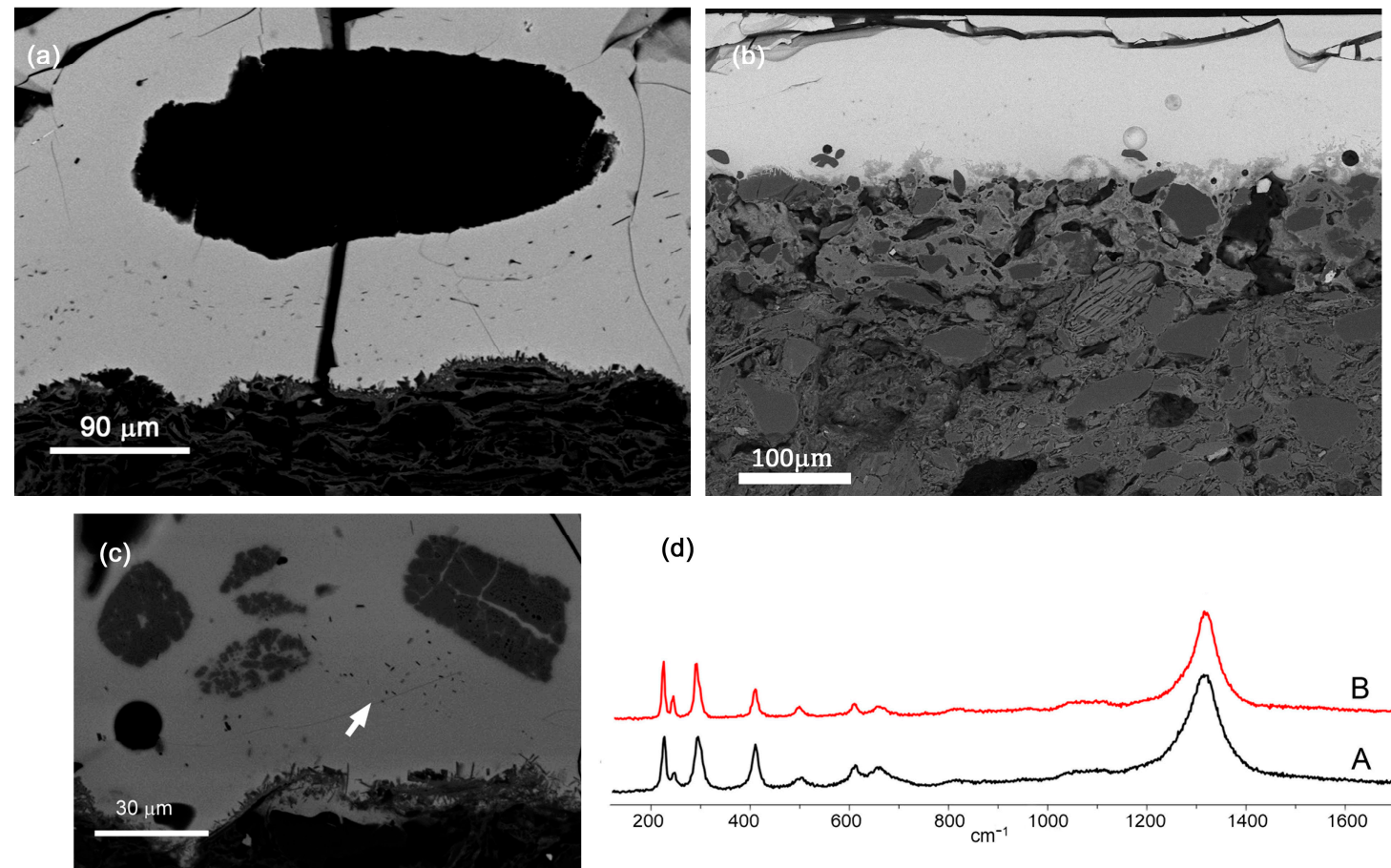

(d)

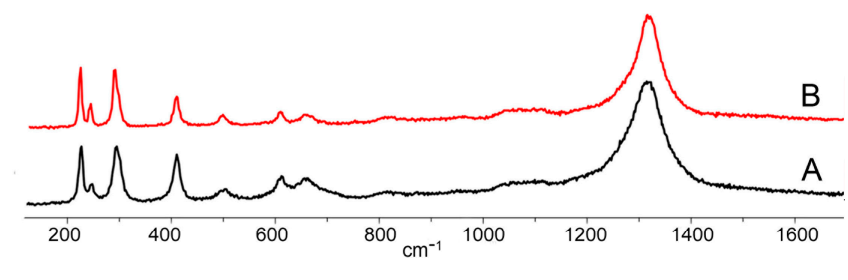

Figure 7. (a) BSE image of the glaze-body interface. A relict potassium feldspar grain can be observed in the glaze. In the glaze-body interface, small spots of neo-formed hematite are also visible (BCN238, TN1); (b) BSE image of the ceramic paste and the glaze. The glaze contains neither relict silicate inclusions nor added iron oxides (BCN271, TN3); (c) BSE image of the glaze. Some relict iron oxides in the glaze are visible (BCN277, TN2). Neo-formed hematite (small dark spots) are marked with a white arrow; (d) Raman spectra: (A) Raman spectrum of hematite acquired on one relict iron oxide (BCN277, TN2); (B) natural sample of hematite used as a reference. 

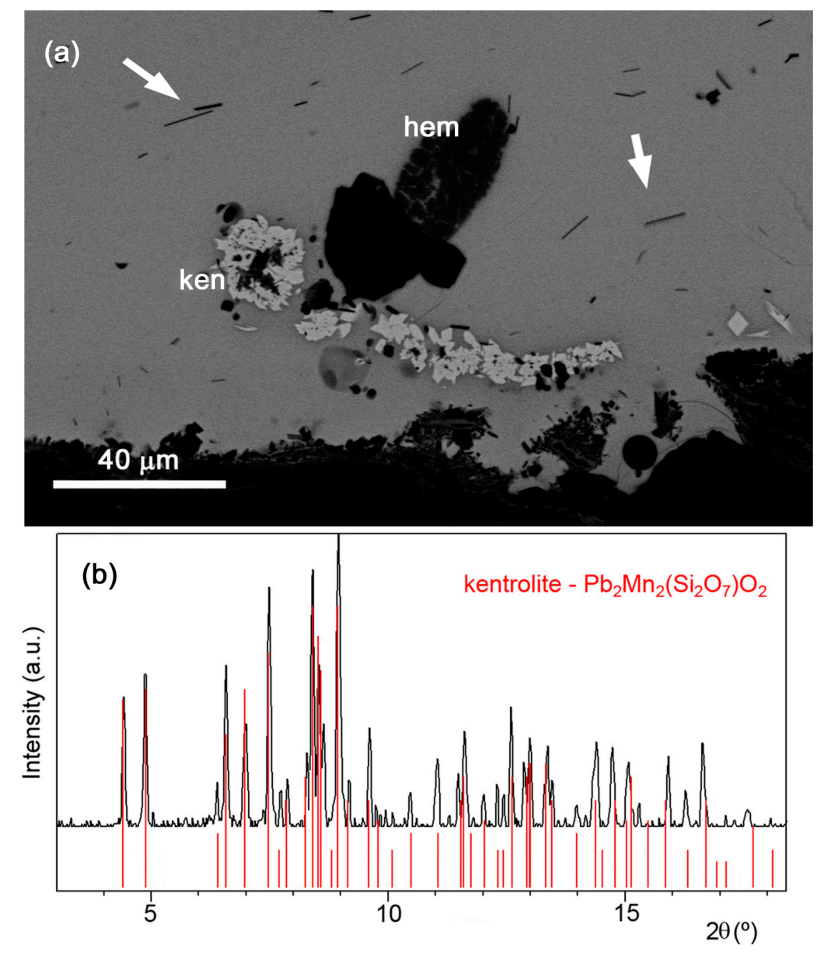

Figure 8. (a) BSE image of the glaze-body interface (BCN281, TN2). Light Mn-rich crystallites of kentrolite (ken), relict hematite (hem), and thin sections of neo-formed hematite (marked with white arrows) can be observed. (b) XRD patterns of the analysed crystals. The reference pattern corresponds to JCPDF 01-075-2088 for kentrolite.

\section{Discussion}

The analyses permit the distinction of three main groups clearly related to different manufacturing techniques, with regards to the ceramic bodies, glazes, and technology. In respect to the group TN1, it is possible to confirm the initial archaeological assumption, classifying it as an Albisola import. $\mathrm{TN} 1$ is clearly distinguished from the other groups, due to remarkable differences in $\mathrm{Mg}, \mathrm{Ni}$, and $\mathrm{Cr}$ concentrations [16]. These values can be related either to the amphibolites of the Ligurian Crystalline Massifs (Albisola and Savona) or to the Jurassic ophiolites of the Montenotte Unit and the Voltri Group, which are in contact with the Savona Massif $[26,27]$. The samples of this group show good technical and aesthetic quality. The walls of the shards are thick, but the bodies are hard and sonorous because of the high firing temperatures and consequent vitrification of the matrix. The Fe-rich clay and the frequent silicate inclusions give the pottery a good thermal resistance. The double firing is underlined by the moderately developed glaze-body interface; while the homogeneous oxidation is due to firing in the saggars. In fact, these refractory clay containers preserve the pottery from sudden changes in temperature, steam, flames, and impurities that could develop during the firing process.

In contrast, the samples included in the TN2 were considered imitations. The petrographic examination of their pastes denotes variations in the fabric textures that could suggest the use of distinct manufacturing techniques for these products. Compared to the TN1, the TN2 paste recipe is characterized by a lower $\mathrm{CaO}$ content. Furthermore, TN3 shows a lower $\mathrm{MgO}$ content, linked to the scarce occurrence of mafic minerals in the ceramic paste.

In regards to the technology production of the glazes, it is evident that a strong relationship exists between the Albisola reference samples and the TN1 and TN2 groups. The $\mu$-Raman spectroscopy study made it possible to state that the iron oxides, cited by Napoleonic Prefect Chabrol de Volvic in his report, correspond to hematite grains not completely dissolved in the glaze. This evidence confirms the addition of iron oxides as a colouring agent to obtain honey glazes, which were imposed over the red 
body to produce the characteristic brown colour of the pottery. The presence of undissolved quartz and feldspar inclusions is probably related to the way they were added to the glazes, as sand instead of frit. Therefore, from these observations, one can infer that TN2 are-in terms of raw materials and paste recipes-local products which emulate the method of production of Albisola glazes. This supports the hypothesis of a perpetuation and transmission of the techniques used at Albisola workshops. A technical transmission may have occurred by the arrival of Albisola potters in Catalonia, as is attested for other Spanish and French sites [13,28-33]. In the case of some French imitations from the workshop of Jouques (Provence), the archaeometric analyses revealed the use of a similar glaze recipe compared to the one used for the Albisola pottery $[18,19,25]$.

In contrast, group TN3 reveals a completely different technology production, which must be related to local manufactures without any technical relationship to the Albisola TNW. In thin section, the glazes are uncoloured and thicker. Iron oxides were not added intentionally and quartz and feldspars grains were not found. At the chemical level, the presence of a high aluminium content and a smaller amount of iron is probably related to the interaction between the glaze and the ceramic body. Likewise, the absence of technical relationships to the Albisola potters was observed in the case of some French imitations from Roquefeuille (Provence) [18]. Compared to the originals, the imitations from Roquefeuille showed coarser and more calcareous bodies, glazes of lower quality, and simple solutions adopted to imitate the original decorations [18].

Concerning the dark decorations, kentrolite $\left(\mathrm{Pb}_{2} \mathrm{Mn}_{2} \mathrm{Si}_{2} \mathrm{O}_{9}\right)$ crystallites are found in $\mathrm{TN} 2$, near to the glaze-body interface. Kentrolite is a rare mineral of the sorosilicate group [19,34], which forms a complete solid solution with melanotekite $\left(\mathrm{Pb}_{2} \mathrm{Fe}_{2} \mathrm{Si}_{2} \mathrm{O}_{9}\right)$, its ferric analogue [19,34]. The growth of kentrolite crystallites indicates a manganese-rich pigment and suggests an application of the pigment directly to the ceramic body. Kentrolite and neo-formed hematite crystallites, such as those observed in TN2 glazes, are fingerprints of temperature. In fact, replications made under laboratory-controlled conditions showed that their coexistence in a glaze matrix suggests a firing temperature $<925^{\circ} \mathrm{C}$ [25]. On the other end, the lack of Mn/Fe precipitated in the dark decorations of TN1 and TN3 can be explained by a higher firing temperature, when compared to those of TN2. The manganese and iron dissolved in the decorated areas of these glazes are responsible for the black-brownish colour of these decorations. The presence of hexagonal neo-formed hematite crystallites in both TN1 and TN3 is in good agreement with our experimental data. This makes possible to suggest a firing temperature of $>925^{\circ} \mathrm{C}$ for TN1 and TN3 glazes [25].

\section{Conclusions}

The integrated research methodology applied in this study has successfully allowed the distinction between local imitations and Albisola imports. These show a good technical quality, which is one of the reasons for their immediate and important success on the international market. This study, of two Albisola imports found in Barcelona (TN1), confirms the technical report of Napoleonic Prefect Chabrol de Volvic regarding the materials and method of production of Albisola TNW:

- The paste recipe required the use of locally available raw materials, such as red clay and marl, which were mixed in different proportions. The pastes were probably made of a mixture predominantly of Fe-rich alluvial clays and fossiliferous Pliocenic marls.

- The pottery was fired in two stages. The relatively thin interfaces between glazes and ceramic bodies corroborate the double firing, while the homogeneous oxidation agrees with the firing in saggars.

- The addition of one twelfth of iron oxide was used to obtain orange-brown glazes. Hematite grains have been identified by Raman in TN1 (and in TN2 imitations).

- The use of sand in the glazing mixture. The relic silicate inclusions in the glazes, suggest the direct use of quartz-rich sand instead of a vitrified frit. 
- The manganese and iron dissolved in the decorated areas of the glazes are responsible for the black-brownish colour shown by these decorations. The lack of Mn/Fe precipitates in TN1 (and in TN3 imitations) glazes can be explained by a high firing temperature $\left(>925^{\circ} \mathrm{C}\right)$.

The results obtained also show technical similarities between the original Albisola TNW (TN1) and one of the local productions. The TN2 group was produced using local clays and a glaze recipe very similar to the one used for Albisola TNW. This is evident from the chemical composition of the glazes, the addition of iron oxides and sand in the glazing mixture, and eventually, from the thickness of the glazes. The technical relationship between the Ligurian TNW and the imitations of the TN2 group is a clear indication of the direct transfer of knowledge, and possibly the movement of potters from Albisola to Barcelona. However, the analyses carried out on the dark decorations revealed that the TN2 glazes were fired at a lower temperature $\left(<925^{\circ} \mathrm{C}\right)$ than the original Albisola glazes.

Other imitations (TN3) were made using a different type of local clay from the one used in TN2, indicating a different workshop. The glaze recipe used in TN3 is also completely different from the groups TN1 and TN2. The glazes do not contain hematite grains and the iron content of the glaze is lower than TN1 and TN2. Furthermore, sand inclusions (quartz and feldspar grains) were not found in the glazes which were also thicker than those of TN1 and TN2. This demonstrates how the success of the Taches Noire ware forced other workshops to copy it in order to satisfy the local demand through wares of a different quality. In conclusion, this research illustrates the added value of a scientific approach to the study of provenance and processes of ceramic production. The features of the pastes confirmed the identification of local imitations of TNW. For some of the imitations the glaze recipe was that of the Abisola products, unveiling strong evidence for technology transfer between the Albisola and Barcelona productions.

Author Contributions: R.D.F. conceived and designed the research. R.D.F., C.C. and R.C. have conducted the experiments and analyzed the data from OM and SEM measurements on the ceramic bodies; R.D.F., L.C., C.C. and O.V. conducted and analyzed the data from SEM, micro-Raman and SR- $\mu$-XRD measurements on the glazes and decorations. R.D.F. wrote the first version of the manuscript. All the authors contributed to the final version of the paper.

Acknowledgments: The first author thanks Joan Carles Melgarejo and the Department of Crystallography and Mineralogy (UB, University of Barcelona) for providing the samples of natural hematite. Thanks to the Museu d'Història de Barcelona (MUHBA) for the archaeological samples and to Judit Molera and Laura Negretti for the SEM analyses. OM analyses of the ceramic bodies are part of the Project "Tecnolonial, Impacto tecnológico en el Nuevo Mundo colonial. Aculturación en arqueología y arqueometría cerámica" (HAR2008-02834/HIST), funded by the Ministerio de Ciencia e Innovación (Spain). SEM analyses of the ceramic bodies were funded by the University of Genova. The study of the glazes and brown decorations is part of the Project "Characterization of the micro-crystallites embedded in the glaze decorations of the Original Taches Noires Wares and its Imitations" funded by the Spanish Ministerio de Economía y Competitividad (Project CGL2013-42167-P). SEM analyses of the glazes were partially funded by CICYT grant MAT2013-41127. The authors are grateful to anonymous referees for their constructive review of this manuscript.

Conflicts of Interest: The authors declare no conflicts of interest.

\section{References}

1. Cameirana, A. La “terraglia" nera ad Albisola all'inizio dell'800. In Proceedings of the Atti III Convegno Internazionale della Ceramica, Albisola, Italy, 31 May-2 June 1970; Centro Ligure per la Storia della Ceramica, All'Insegna del Giglio: Firenze, Italy, 1970; pp. 63-95.

2. Cameirana, A. La ceramica albisolese a "Taches Noires". In Proceedings of the Atti del X Convegno Internazionale della Ceramica, Albisola, Italy, 22-29 May 1977; Centro Ligure per la Storia della Ceramica, All'Insegna del Giglio: Firenze, Italy, 1977; pp. 277-293.

3. Milanese, M.; Biagini, M.; Ventura, D. La ceramica “à Taches Noires”: Un indicatore dell'archeologia postmedievale mediterranea. In Proceedings of the Atti del XXVII Convegno Internazionale della Ceramica, Albisola, Italy, 27-29 May 1994; Centro Ligure per la Storia della Ceramica, All'Insegna del Giglio: Firenze, Italy, 1994; pp. 337-354. 
4. Blake, H. Pottery exported from Northwest Italy between 1450 and 1830: Savona, Albisola, Genoa, Pisa, and Montelupo. In Archaeology and Italian Society; Prehistoric, Roman and Medieval Studies; Barker, G., Hodges, R., Eds.; International Series 102; BAR: Oxford, UK, 1981; pp. 99-124.

5. Chabrol De Volvic, G. Statistiques des provinces de Savone, d'Oneille, d'Acqui et de partie de la province de Mondovi, formant l'ancien Département de Montenotte; Jules Didot: Paris, France, 1824.

6. Barton, K.J. Terres cuites provenant de la fortesse de Luisbourg. In Historie et Archéologie; Direction de Lieux et de Parcs Historiques Nationaux, Parcs Canada: Ottawa, ON, Canada, 1970; Volume 55, pp. 4-78.

7. Cavaletto, M. La ceramica à Taches Noires. In Cuneo dal XIII al XVI Secolo; Impianto ed Evoluzione del Tessuto Urbano; L'Arciere: Cuneo, Italy, 1989; pp. 183-189.

8. Dadea, M. La cerámica "à taches noires" a Cagliari. In Proceedings of the Atti del XXVII Convegno Internazionale della Ceramica, Albisola, Italy, 27-29 May 1994; Centro Ligure per la Storia della Ceramica, All'Insegna del Giglio: Firenze, Italy, 1994; pp. 295-299.

9. Foy, D.; Richez, F.; Vallauri, L. La céramique en usage dans l'atelier de Verrier de Roquefeuille (Pourrières, Var): Exemple d'un dépotoir domestique de la première moitié du XVIIIe siècle. Archeologie du Midi Medieval 1986, 4, 135-149. [CrossRef]

10. Long, L.; Richez, F. L'épave Grand-Conglué 4. In Un goût d'Italie, Céramiques et céramistes italiens en Provence du Moyen Âge au XXème siècle; Narration: Aubagne, France, 1993; pp. 93-95.

11. Moussette, M. La poterie d'Albisola en Amérique du Nord. In Un goût d'Italie, Céramiques et céramistes italiens en Provence du Moyen Âge au XXème siècle; Narration: Aubagne, France, 1993; pp. 98-99.

12. Petrucci, J. Céramiques provençales et albisolaises du 18éme au Canadà. In Proceedings of the Atti del $X$ Convegno Internazionale della Ceramica, Albisola, Italy, 22-29 May 1977; Centro Ligure per la Storia della Ceramica, All'Insegna del Giglio: Firenze, Italy, 1977; pp. 269-276.

13. Amouric, H.; Vallauri, L. La fabrique de Villemus. In Un goût d'Italie. Céramiques et céramistes italiens en Provence du Moyen Âge au XXème siècle; Narration: Aubagne, France, 1993; pp. 118-120.

14. Beltrán de Heredia Bercero, J.; Miró i Alaix, N. El comerç de ceràmica a Barcelona als segles XVI-XVII: Itàlia, França, Portugal, els tallers del Rin i Xina. Quarhis. Quaderns d'Arqueologia i Història de la Ciutat de Barcelona 2010, 6, 15-91.

15. Beltrán de Heredia Bercero, J.; Capelli, C.; Di Febo, R.; Madrid i Fernández, M.; Buxeda i Garrigós, J. Imitaciones de ceràmicas Taches Noires en Barcelona en el siglo XVIII. Datos arqueológicos y arqueométricos. In Proceedings of the Actas do X Congresso Internacional A Cerâmica Medieval no Mediterrâneo, Silves, Portugal, 22-27 October 2012; Camera Municipal de Silves: Silves, Portugal; Campo Arqueológico de Mértola: Mértola, Portugal, 2015; pp. 613-618.

16. Di Febo, R. La ceràmica de Barcelona entre els segles XIII i XVIII a través de la seva caracterització arqueomètrica. El paper de l'anàlisi petrográfica. Ph.D. Thesis, University of Barcelona, Barcelona, Spain, 2016.

17. Capelli, C.; Richez, F.; Vallauri, L.; Cabella, R.; Di Febo, R. L'épave du Grand Congloué 4: caractérisation archéologique et archéométrique d'un lot de céramiques a Taches noires de Albisola. In Proceedings of the Atti del XLV Convegno Internazionale della Ceramica, Savona, Italy, 25-26 May 2012; Centro Ligure per la Storia della Ceramica, All'Insegna del Giglio: Firenze, Italy, 2013; pp. 7-16.

18. Capelli, C.; Di Febo, R.; Amouric, H.; Cabella, R.; Vallauri, L. Importazioni e imitazioni locali di ceramica a Taches Noires in Provenza nel XVIII-XIX secolo. Dati archaeologici e archaeometrici. In Proceedings of the Atti del XLIX Convegno Internazionale della Ceramica, Savona, Italy, 27-28 May 2016; Centro Ligure per la Storia della Ceramica, All'Insegna del Giglio: Firenze, Italy, 2017; pp. 339-345.

19. Di Febo, R.; Molera, J.; Pradell, T.; Vallcorba, O.; Melgarejo, J.C.; Capelli, C. Thin section petrography and SR- $\mu$ XRD for the identification of micro-crystallites in the brown decorations of ceramic lead glazes. Eur. J. Mineral. 2017, 29, 861-870. [CrossRef]

20. Fauth, F.; Peral, I.; Popescu, C.; Knapp, M. The new Material Science Powder Diffraction beamline at ALBA Synchrotron. Powder Diffr. 2013, 28, 360-370. [CrossRef]

21. Hammersley, A.P.; Svensson, S.O.; Hanfland, M.; Fitch, A.N.; Häusermann, D. Two-Dimensional Detector Software: From Real Detector to Idealised Image or Two-Theta Scan. High Press. Res. 1996, 14, $235-248$. [CrossRef] 
22. Giammarino, S.; Giglia, G.; Capponi, G.; Crispini, L.; Piazza, M. Carta Geologica della Liguria-Scala 1:200000; Lab. Cartografia digitale e GIS del Dipartimento di Scienze della Terra dell’Univerisità di Siena, Litografia Artistica Cartografica: Firenze, Italy, 2002.

23. Riba, O.; Colombo, F. Barcelona: la Ciutat Vella i el Poblenou; Assaig de Geologia Urbana, Institut d'Estudis Catalans: Barcelona, Spain, 2009.

24. ARQ।UB. Cultura Material i Arqueometria, Universitat de Barcelona. Available online: http://www.ub. edu/gracpe/arqub/index.html (accessed on 26 April 2018).

25. Di Febo, R.; Molera, J.; Pradell, T.; Vallcorba, O.; Capelli, C. Technological implications of neo-formed hematite crystals in ceramic lead glazes. Sci. Technol. Archaeol. Res. 2018, 4. [CrossRef]

26. Vanossi, M. Alpi Liguri; Guide Geologiche Regionali 2; Società Geologica Italiana: Milano, Italy, 1991.

27. Cimmino, F.; Cortesogno, L.; Lucchetti, G. Orneblende nelle anfiboliti dei massicci cristallini liguri. Rendiconti Società Italiana di Mineralogia e Petrologia 1976, 32, 591-616.

28. Álvaro Zamora, M.I. Sobre los modos de irradiación de la cerámica ligur y la presencia de ceramistas de esta procedencia en la Zaragoza del siglo XVII. Artigrama 1987, 4, 137-156.

29. Zamora, Á.; Isabel, M. La penetración de la moda cerámica ligur en los alfares peninsulares de los siglos XVII-XVIII: el caso de Aragón. XV Jornades d'Estudis Històrics Locals: Transferències i comerç de ceràmica a l'Europa mediterrània (segles XIV-XVII); Institut d'Estudis Baleàrics Palma de Mallorca: Palma, Spain, 1997; pp. 185-212.

30. Zamora, Á.; Isabel, M. La emigración de ceramistas ligures a Aragón (España) en el siglo XVII y la influencia de sus repertorios decorativos en la producción de los alfares locales. In Proceedings of the Atti XXXI Convegno Internazionale della Ceramica, Albisola, Italy, 28-29 May 1999; Centro Ligure per la Storia della Ceramica, All'Insegna del Giglio: Firenze, Italy, 1999; pp. 151-169.

31. López Torres, P.; Rueda Galán, M.M. La imitación de la "berettina" en las producciones sevillanas. In Proceedings of the Atti del XXXI Convegno Internazionale della Ceramica, Albisola, Italy, 28-29 May 1999; Centro Ligure per la Storia della Ceramica, All'Insegna del Giglio: Firenze, Italy, 1998; pp. 171-177.

32. Pleguezuelo, A. Lozas y azulejos de Sevilla en el Siglo de Oro. In Lozas y azulejos de la colección Carranza, $n$. 1; Pleguezuelo, A., Ed.; Junta de Castilla-La-Mancha: Toledo, Spain, 2002; pp. 203-226.

33. Carta, R. Un gruppo di maioliche liguri a smalto berettino rinvenute nell'Alhambra di Granada. In Proceedings of the Atti del XXXV Convegno Internazionale della Ceramica, Savona, Italy, 31 May-1 June 2002; Centro Ligure per la Storia della Ceramica, All'Insegna del Giglio: Firenze, Italy, 2003; pp. 129-139.

34. Ito, J.; Frondel, C. Syntheses of the kentrolite-melanotekite series. Arkiv för Mineralogy och Geologie 1966, 4, 387-390.

(C) 2018 by the authors. Licensee MDPI, Basel, Switzerland. This article is an open access article distributed under the terms and conditions of the Creative Commons Attribution (CC BY) license (http://creativecommons.org/licenses/by/4.0/). 